\title{
Paschalis M. Kitromilides, Religion and Politics in the Orthodox World: The Ecumenical Patriarchate and the Challenges of Modernity (London: Routledge, 2019), 144 p., ISBN: 9780815394648
}

Ionuț Biliuță*

Professor Paschalis M. Kitromilides remains one of the most respected voices in Enlightenment and Early Modern Studies, emphasizing the relationship between the lights of reason and tolerance and the Orthodox Church under the Ottoman yoke during the eighteenth and the early nineteenth century. His previous books address the circulation of Enlightenment ideas in Orthodox intellectual milieus, the tensions between modernity, Hellenism, and religiously infused Tradition in the Greek-speaking world before and after the French Revolution, the impact of modernity as such on more traditional and religious environments as those associated with the Orthodox Church.

Prefaced by Metropolitan Ioannis Ziziuoulas of Pergamon, the book summarizes all the ideas mentioned before by the author. It provides a re-reading of his previous arguments under a new scope that links the Patriarchal See in Constantinople with the rest of the Orthodox Commonwealth. Professor Kitromilides applies with skill and diligence his previous theories upon a case study of the Church of Constantinople, also known as the Ecumenical See. The aim of the present book is ,to consider the question of the interplay of religion and politics in the Orthodox world by trying to recover and bring forth religions understanding of itself and place in the world and appraise its inescapable political involvements in these terms." (p. 1)

One of the main focal points of the book relates to an interpretation of history through the lenses of Tradition that enables the author to propose a counter-history engendered in a spiritual key. From the introduction, the Athenian professor raises awareness about the pitfalls, misconceptions and limitations that befell and plagued Western historiography. A student should avoid these pitfalls while having a clear grasp of Orthodoxy in its whole meaning: both historical and spiritual. Church History and Enlightenment studies stand in Kitromilides historical perspective not as sworn enemies but rather as two parts of the same story that linked Western European developments in philosophy with the ecumenical, universal Orthodoxy in the early days of modernity.

The first chapter entitled "The Orthodox Church and the Enlightenment" (p. 12-21) discusses the interaction of the Greek clergy repre-

\footnotetext{
* Ionuț Biliuță, Gheorghe Șincai Institute for Social Sciences and the Humanities, Romanian Academy, 10A Al. Papiu Ilarian, Tg. Mures, 540074, Mures, Romania, ionut.biliuta@academia-cj.ro.
} 
sented by Metropolitan Ignatius of Ungrawallachia with the representatives of the enlightened Western intelligentsia in Italy represented by G. P. Vieusseux and their exchange of letters. Going against mainstream historiography of the Balkans in the early nineteenth century that depicted Orthodox clergymen as reluctant to embrace the Enlightenments ideals of national awareness and freedom, Kitromilides stresses the fact that Ignatius played "the role of the "informal' diplomat of the Greek Revolution" (p. 19), one who envisaged bridges with the Western intellectual voices in support of the Greeks' revolt against the Ottoman rule. Throughout the letters, Ignatius emphasis on the different path of the Enlightenment movement in Eastern Europe summarizes his views about the necessity of a seminal synthesis between the Western values spreading in Eastern Europe in the post-French Revolution world (the culture of lights, modernization, liberal government, and secular education) and the Orthodox Tradition (p. 20). According to a „Moderate Enlightenment” perspective (p. 20) and seeing the benefits of secular education and culture for the progress of the Greeks, Ignatius intended to reconcile two irreconcilable realities (Modernity and Orthodoxy) for the best of his nation.

The second chapter, "The Orthodox Church in modern state formation in Southeastern Europe" (p. ), discusses the various still controversial and highly significant interactions between the Orthodox Church and nationalism in various ethnic and regional contexts. The chapter is based on two research questions. The first addresses how the young national states subdued the institution of the Orthodox churches in a short period (the 1820s-1880s). Furthermore, what the consequences were for Orthodox unity and the institution of the Church after the emergence of splinter national churches in the Balkans (p. 25). According to Kitromilides, two stages describe the reactions and reception of the ideologies of modernity, namely nationalism, by Orthodox clergy members. The second addresses the church/s participation and attitude towards the rise of the national states in the Balkans (p. 29). In the first period, due to the violence of the French Revolution and the spread of the revolutionary ideas in Southeastern Europe, the Orthodox clergymen headed by Patriarch Gregory V of Constantinople expressed their disdain towards the French regicide and the reversal of the Old Order. Faced with revolutionary ideas taking over the minds of the Balkan intellectuals, "the Orthodox Church and the canonical order it upheld found itself defending the ecumenical values of Christian universalism against the parochial values of nationalism." (p. 30)

Nevertheless, the drama of the Greek struggle for independence from the Ottoman rule caught the minds of Orthodox clergymen, who eventually accepted the national ideal and realized the transition of their church into 
the age of nationalism. In Greece, bishops such as Daniel of Tripolitza, Cyril of Corinth, and Joseph of Androusa embraced nationalism and the Greek national state, becoming politicians and top bureaucrats rather than hierarchs of the church. The process of nationalizing the clerical class and the transition from the ecumenical to the nationalist stance led to the next stage when the newly formed nation-states imposed their authority upon their churches and broke their communion from the Constantinople Patriarchate through the autocephaly. Reduced to state departments, with their clergy functioning as state bureaucrats, saddled with the government's constant interferences in their affairs and with their monasteries` wealth secularized and dissolved, the Orthodox churches of Romania, Greece, Serbia found common ground for dialogue with nationalism and the state by employing the language of the canon law (p. 33).

The third chapter provides the reader with a summary of the reactions to the challenge of nationalism engendered by the Ecumenical Patriarchate in the nineteenth century (p. 43-58). Assuming that „nationalism meant fundamentally secularization” (p. 45), professor Kitromilides argues in favor of the Patriarchal See of Constantinople depicting its reaction to the spread of nationalism as ,a response of a religious institution to a challenge posed to its core values and self-definition deriving from a centuries-old tradition by a secular threat to its heritage." (p. 43) While the Romanian and Greek states ensured the autocephaly of their churches, the Ecumenical Patriarchate under Gregory $\mathrm{V}$ attempted to resist the spread of nationalism through the employment of censorship, publications of journals such as Kalliope in Vienna, and the control over the Greek schools spread across Ottoman-controlled Eastern Europe (p. 54-55). Also, during the reign of Sultan Abdul Mecid I (1839-1861), the Orthodox Church in the Ottoman Empire enjoyed a short period of expansion reflected in an increasing number of newly built large churches in Constantinople and the other major cities of the empire. The rule of Sultan Abdulhamid II (1876-1909) and the movement of the Young Turks curtailed to some extent the fruitful development of the Orthodox Church, and some of the privileges graciously awarded by the sultan were withdrawn.

While chapter four (p. 60-70) tracks the history of the Orthodox Church in the Ottoman Empire from its flourishing condition at the beginning of the twentieth century and the catastrophe that followed the end of the Greek-Turkish war. This particular event saw the dismantling of the prominent Greek communities from Anatolia. Chapter five, the best and most consistent chapter of the book (p. 72-89), follows the history of the Ecumenical Patriarchate during the Cold War (1946-1991). From the beginning, the author distinguishes between two levels of historical perception, 
that is, "the external history" where the impact of the Cold War upon the church could be traced and ,an internal history, the inner life of the Church and ecclesiastical activity" (p. 73). The author paints a picture of the intricate game of relations with the Turkish and Soviet authorities in curtailing the authority of the Constantinople Patriarchate and establishing Moscow as the new center of the Orthodox Church. He also looks at the diplomatic endeavors of the Western powers such as the United States and Greece as opposed to the Soviet Union to elect favorable patriarchs and the ecumenical détente of the Patriarchal See, especially after the 1948 decision to take part in the World Council of Churches. The meeting of Patriarch Athenagoras with Pope Paul VI in Jerusalem (December 1964) followed by the visit of the Roman Pontiff to Constantinople in 1967 is another key-point underlined by the author. As professor Kitromilides remarks, throughout the Cold War period in all these contacts with various states and ecclesiastical entities, the Patriarchate in Constantinople acted upon the same basic principles and lines of action that preserved the millennial institution of the Church. The Patriarchate withstood Turkish pressure and ensured the canonic primacy of the See of Constantinople in competition with that of Moscow without damaging Orthodox communion of faith. Also, during the Cold War the representatives of the Ecumenical See explored the possibility of Christian unity and dialogue with other Christian churches.

The last two chapters of the book represent a change in tone from the first four as the narrative moves from a historical to a more systematic approach when dealing with recent years. The first under the title "A religious international?" (p. 92-106) approaches the history of the Patriarchal See in Constantinople from the perspective of its „internationalism” (p. 99), of Patriarch Bartholomewss intertwining with ecological issues (p. 99-100) and the transformation of the Patriarchate into a leading canonical authority - a last see of appeal - in the Orthodox World (p. 101). While defying secular internationalism with all its core values, the strategy employed by Patriarch Bartholomew stemmed the tide of nationalist passions in Orthodox sister churches around the world by instilling trust and confidence in the Ecumenical Patriarchate as the arbiter of intestine and transnational disputes regarding ecclesiastical jurisdictions. He also laid the necessary groundwork for re-establishing Constantinople/Istanbul as the leading voice in the chorus of Orthodox voices and re-kindled interest in following the millennial tradition of the Church that presented the Church in Constantinople as the beacon of ecumenical and canonical light (p. 103).

Finally, „Orthodoxy, nationalism and ethnic conflict” (p. 107-111) stand as the final remarks of the book. Professor Kitromilides proposes three 
conclusions: Orthodoxy equals universality, that identifying Orthodoxy with nationalism stands as an example of „anachronistic judgment and misunderstanding of the historical record" (p. 108). Finally, because they have been intertwined with nationalism, all national Orthodox churches bear the responsibility for these anachronistic judgments and historical tragedies that befell the ecumenical Orthodox church. Though the analysis seems to be harsh, and the conclusions reached by the author may seem radical in their assessment of the historical development of Orthodoxy in the last three centuries, the reader should grapple with the main arguments of the present book. These reasonings should be assessed and reconsidered according to the historical path undertaken by Eastern Christianity in Modernity.

"Religion and Politics in the Orthodox World" stands out as one of the most exciting and challenging contributions penned by Paschalis M. Kitromilides after more than thirty years of research and publishing in the field of Enlightenment studies, Orthodox history and political science. It should be regarded as an enlightening companion in the history of one of the most globally disregarded and understudied churches: the Ecumenical Patriarchate of Constantinople. Another fundamental point made by the book illustrates Professor Kitromilides' intellectual acumen and his academic goals over the years that he instilled upon his students and followers. The book also presents a non-partisan alternative of scholarly analysis of Orthodoxy from historical and political science perspectives, remarkably similar in scope to the one contemporary church history provides. Dr. Kitromilides challenges face-on the secular undertakings in East-European history, religious studies, political science and sociology/anthropology of religion that depict Orthodox Christianity as a backward, institutionally driven entity in post-colonial fashion riveted by bitter rivalries and historical feuds. It should also be read as a summative recapitulation of the main arguments about the Orthodox church as a fundamental constituent part of Eastern European modernity as exposed by the author over the last 30 years in his scholarly work.

Masterfully written, with a vast array of primary and secondary sources, the present book should be received both with amazement and curiosity, and the author is entitled to our gratitude for courageously approaching such a controversial topic. Amazement for the fantastic amount of work entered in this short but consistent tome and curiosity due to its counter-mainstream perspective. Professor Kitromilides book should be valuable and demanding reading for pundits and students of Eastern European history, religious studies, church history, comparative religion/politics, political science and Orthodoxy history. It would also be a much welcome addition for historical theology, ecumenism, church and modernity, but also non-specialists alike. 